\title{
PENGARUH KECERDASAN EMOSIONAL, KARAKTERISTIK PEGAWAI DAN MOTIVASI KERJA TERHADAP KINERJA PEGAWAI PADA KANTOR PELAYANAN PAJAK PRATAMA MEDAN TIMUR
}

\author{
Yusrani Lubis \\ Universitas Islam Sumatera Utara \\ yusranilubis@gmail.com
}

\begin{abstract}
The formulation of the problem in this research is how the influence of emotional intelligence on employees performance. How influence of employees characteristic on employees performance. How influence of work motivation on employees performance. How influence of emotional intelligence, employees characteristic and work motivation on employees performance. The purpose of this research is for know influence and analize of emotional intelligence on employees performance. For know influence and analize of employees characteristic on employees performance. For know influence and analize work motivation on employees performance. For know influence and analize emotional intelligence, employees characteristic and work motivation on employees performance. The sample in this research is 86 employees, with data analysis technique used is multiple linear regression analyze. The results of this research explain that emotional intelligence effect has a positive and significant on employee performance. employees characteristic effect has a positive and significant on employee performance. work motivation effect has a positive and significant on employee performance. emotional intelligence, employees characteristic and work motivation effect have a positive and significant on employee performance
\end{abstract}

Keywords : Emotional intelligence, Employees characteristic, Work motivation, Performance

\begin{abstract}
ABSTRAK : Rumusan masalah dalam penelitian ini adalah bagaimana pengaruh kecerdasan emosional terhadap kinerja pegawai. Bagaimana pengaruh karakteristik pegawai terhadap kinerja pegawai. Bagaimana pengaruh motivasi kerja terhadap kinerja pegawai. Bagaimana pengaruh kecerdasan emosional, karakteristik pegawai dan motivasi kerja terhadap kinerja pegawai. Tujuan penelitian ini adalah untuk mengetahui dan menganalisis pengaruh kecerdasan emosional terhadap kinerja pegawai. Untuk mengetahui dan menganalisis pengaruh karakteristik pegawai terhadap kinerja pegawai. Untuk mengetahui dan menganalisis pengaruh motivasi kerja terhadap kinerja pegawai. Untuk mengetahui dan menganalisis pengaruh kecerdasan emosional, karakteristik pegawai dan motivasi kerja terhadap kinerja pegawai. Sampel dalam penelitian ini berjumlah 86 orang pegawai. Teknik analisis data dalam penelitian ini menggunakan analisis deskriptif dan analisis regresi linier berganda. Hasil penelitian ini menjelaskan bahwa kecerdasan emosional berpengaruh positif dan signifikan terhadap kinerja pegawai. Karakteristik pegawai berpengaruh positif dan signifikan terhadap kinerja pegawai. Motivasi kerja berpengaruh positif dan signifikan terhadap kinerja pegawai. Kecerdasan emosional, karakteristik pegawai dan motivasi kerja berpengaruh positif dan signifikan terhadap kinerja pegawai
\end{abstract}

Kata kunci : Kecerdasan emosional, Karakteristik pegawai, Motivasi kerja, Kinerja

\section{Pendahuluan}

Kantor Pelayanan Pajak Pratama Medan Timur senantiasa berupaya untuk melakukan pembenahan diri sesuai dengan tuntutan lingkungan perubahan yang terjadi di Direktorat Jenderal Pajak. Sejalan dengan tuntutan masyarakat terhadap efektivitas pelaksanaan tugas pokok dan fungsi dalam rangka mendorong terwujudnya good governance, Kantor Pelayanan Pajak Pratama Medan Timur harus mampu menjawab pelaksanaan tugas pokok dan fungsi melalui penerapan mekanisme pertanggungjawaban yang tepat, jelas dan terukur.

Birokrasi merupakan instrumen penting dalam masyarakat yang kehadirannya tak 
mungkin terelakkan dengan konsekuensi logis misi suci yaitu untuk mensejahterakan rakyatnya. Berkenaan dengan upaya pelayanan dan mewujudkan kesejahteraan rakyat, birokrasi publik memberikan andil yang relatif besar. Untuk mencapai tujuan yang mulia dari birokrasi, diperlukan kiranya pegawai yang handal dan cekatan dalam menangkap kebutuhan jaman yang semakin kompleks dewasa ini. Aparatur pemerintah yang mempunyai kejujuran, bisa menjadi suri tauladan bagi publik, memiliki kapasitas intelektual, kinerja, penguasaan teknologi,dan lain-lain. Sejumlah tuntutan kemampuan tersebut merupakan kebutuhan dalam pengembangan sumber daya manusia aparatur pemerintah dalam birokrasi publik di Indonesia.

Hasibuan (2008:66) mengemukakan bahwa ada 4 (empat) unsur-unsur yang terdapat dalam kinerja yaitu hasil-hasil fungsi pekerjaan, faktor-faktor yang berpengaruh terhadap prestasi pegawai, pencapaian tujuan organisasi, periode waktu tertentu. Mangkunegara

(2009:86), mengatakan bahwa kinerja diukur engan instrumen yang dikembangkan dalam studi yang tergabung dalam ukuran kinerja secara umum kemudian diterjemahkan kedalam penilaian perilaku secara mendasar, meliputi kuantitas kerja, kualitas kerja, pengetahuan tentang pekerjaan, pendapat atau pernyataan yang disampaikan, penyusunan kegiatan.

Penelitian yang berkaitan dengan kinerja pegawai telah banyak dilakukan oleh para peneliti terdahulu. Berdasarkan hasil penelusuran studi empiris diatas, variabel pertama yang teridentifikasi mempengaruhi kinerja pegawai adalah kecerdasan emosional. Menurut Goleman (2001:86) kecerdasan emosional adalah kemampuan untuk mengenali emosi diri, mengelola emosi, mengenali emosi orang lain, dan membina hubungan dengan orang lain. Beberapa penelitian terdahulu telah membuktikan bahwa variabel kecerdasan emosional memiliki pengaruh yang berarti terhadap kinerja pegawai (Sontakke (2016) dan Babatunde at.al (2014). Dengan demikian dapat disimpulkan bahwa seorang pegawai yang memiliki kecerdasan emosional yang tinggi (berkaitan dengan kemampuan mengenali emosi diri, mengelola emosi, mengenali emosi orang lain, dan membina hubungan dengan orang lain) maka pegawai tersebut cenderung memiliki kinerja yang tinggi dalam melaksanakan pekerjaannya.
Variabel lain yang teridentifikasi mempengaruhi kinerja pegawai adalah karakteristik pegawai. Teori dari Dubrin (2005:115), menyatakan karakteristik pegawai dapat dilihat melalui minat, sikap dan kebutuhan. Dengan adanya karakteristik yang berupa minat yang tinggi, sikap yang baik serta adanya kebutuhan maka kinerja pegawai juga akan meningkat. Alasan pemilihan Kantor Pelayanan Pajak Pratama Medan Timur sebagai objek penelitian adalah mengingat pentingnya Kantor Pelayanan Pajak Pratama Medan Timur sebagai instansi pemerintah yang mengelola keuangan.

Variabel ketiga yang mempengaruhi kinerja pegawai Kantor Pelayanan Pajak Pratama Medan Timur adalah motivasi kerja. Menurut Robbins (2008:166) motivasi adalah kesediaan untuk mengeluarkan tingkat upaya yang tinggi untuk tujuan organisasi yang dikondisikan oleh kemampuan upaya itu dalam memenuhi beberapa kebutuhan individual. Kebutuhan terjadi apabila tidak ada keseimbangan antara apa yang dimiliki dan apa yang diharapkan. Dorongan merupakan kekuatan mental yang berorientasi pada pemenuhan harapan dan pencapaian tujuan. Dan tujuan adalah sasaran atau hal yang ingin dicapai oleh seseorang individu. Terry (2008:132), teori Herzberg tentang motivasi berpendapat bahwa ada dua faktor ekstrinsik dan instrinsik yang mempengaruhi seseorang bekerja. Termasuk dalam faktor ekstrinsik (hygienes) adalah hubungan interpersonal antara atasan dengan bawahan, teknik supervisi, kebijakan administratif, kondisi kerja dan kehidupan pribadi. Sedangkan faktor intrinsik (motivator) adalah faktor yang kehadirannya dapat menimbulkan kepuasaan kerja dan meningkatkan prestasi atau hasil kerja individu. Fenomena yang terjadi tentang motivasi di Kantor Pelayanan Pajak Pratama Medan Timur, diantara kesempatan dan keterlibatan pegawai khususnya staf dalam memberikan masukan kepada atasan masih kurang optimal dan kesempatan pegawai untuk mengikuti diklat, seminar atau pendidikan dan pelatihan juga dirasakan masih kurang.

Adapun Tujuan penelitian ini adalah :

a. Untuk mengetahui dan menganalisis pengaruh kecerdasan emosional terhadap kinerja pegawai pada Kantor Pelayanan Pajak Pratama Medan Timur.

b. Untuk mengetahui dan menganalisis pengaruh karakteristik pegawai terhadap 
kinerja pegawai pada Kantor Pelayanan Pajak Pratama Medan Timur.

c. Untuk mengetahui dan menganalisis pengaruh motivasi kerja terhadap kinerja pegawai pada Kantor Pelayanan Pajak Pratama Medan Timur.

d. Untuk mengetahui dan menganalisis pengaruh kecerdasan emosional, karakteristik pegawai dan motivasi kerja terhadap kinerja pegawai pada Kantor Pelayanan Pajak Pratama Medan Timur.

\section{Metode Penelitian}

\subsection{Lokasi Penelitian}

Penelitian ini dilakukan di Kantor Pelayanan

Pajak Pratama Medan Timur. Jalan Suka Mulia

No. 17A Medan Maimun-20212.

\subsection{Populasi}

Menurut Sugiyono (2007: 55), populasi adalah wilayah generalisasi yang terdiri atas obyek/subjek yang mempunyai kuantitas dan karakteristik tertentu yang ditetapkan oleh peneliti untuk dipelajari dan kemudian ditarik kesimpulannya. Jadi populasi bukan hanya orang tetapi juga benda-benda alam yang lain. Populasi juga bukan sekedar jumlah yang ada pada objek/subjek yang dipelajari, tetapi meliputi seluruh karakteristik, sifat yang dimiliki objek/subjek itu. Dari pengertian tersebut, maka dapat disimpulkan bahwa populasi merupakan subjek penelitian dimana individu yang akan dikenai perilaku atau dapat dikatakan sebagai keseluruhan objek penelitian yang akan diteliti. Maka yang menjadi populasi dalam penelitian ini adalah pegawai Kantor Pelayanan Pajak Pratama Medan Timur yang berjumlah 109 orang.

\subsection{Sampel}

Untuk menentukan jumlah sampel, digunakan pendapat Slovin dalam Sekaran dan
Bougie (2010:112) dengan menggunakan formula sebagai berikut :

$$
\text { a. } n=\frac{N}{1+N \mathrm{e}^{2}}
$$

Keterangan :

n : Jumlah Sampel

$\mathrm{N} \quad$ : Jumlah Populasi

$e \quad$ : Kesalahan yang ditolerir dalam penarikan sampel yaitu 0,05 .

Berdasarkan formula diatas, selanjutnya dapat dihitung jumlah sampel dalam penelitian ini sebagai berikut :

$$
\begin{aligned}
& \mathrm{n}=\frac{109}{1+109(0,05)^{2}} \\
& \mathrm{n}=\frac{109}{1.27} \\
& \mathrm{n}=85.82=86 \text { orang }
\end{aligned}
$$

Setelah perhitungan di atas, penetapan jumlah sampel dalam penelitian ini menggunakan metode stratified random sampling yaitu penarikan sampel berdasarkan pada strata populasi pada setiap bagian, sehingga sampel dalam penelitian ini berjumlah 86 orang pegawai, dengan rincian sebagai berikut :

Tabel 1

Distribusi sampel penelitian berdasarkan jabatan

\begin{tabular}{|c|l|c|}
\hline No & Keterangan/Jabatan & $\begin{array}{c}\text { Jumlah } \\
\text { (Orang) }\end{array}$ \\
\hline 1 & Kepala Seksi & 8 \\
\hline 2 & $\begin{array}{l}\text { Account } \\
\text { Representative (AR) }\end{array}$ & 35 \\
\hline 3 & Fungsional & 16 \\
\hline 4 & Pelaksana & 27 \\
\hline \multicolumn{2}{|c|}{ Total } & 86 \\
\hline
\end{tabular}

Sumber : Kantor Pelayanan Pajak Pratama Medan Timur,

\begin{tabular}{|c|c|c|c|c|}
\hline No & Defenisi Variabel & $\begin{array}{c}\text { Jenis } \\
\text { Variabel }\end{array}$ & Indikator & $\begin{array}{c}\text { Skala } \\
\text { Pengukuran }\end{array}$ \\
\hline 1. & $\begin{array}{l}\text { Kecerdasan emosional sebagai } \\
\text { kemampuan mengenali diri sendiri, } \\
\text { serta mengelola emosi pada diri } \\
\text { sendiri dan dalam hubungan } \\
\text { dengan orang lain. } \\
\text { Goleman (2008:512) }\end{array}$ & $\begin{array}{l}\text { Variabel } \\
\text { bebas }\end{array}$ & $\begin{array}{l}\text { 1). Kesadaran diri } \\
\text { 2). Pengaturan diri } \\
\text { 3). Motivasi } \\
\text { 4). Empati } \\
\text { 5). Ketrampilan sosial } \\
\text { Goleman (2008:528) }\end{array}$ & $\begin{array}{l}\text { Skala } \\
\text { Ordinal }\end{array}$ \\
\hline & Karakteristik individu adalah & Variabel & 1). Ketrampilan & \\
\hline
\end{tabular}
2019

\subsection{Definisi Operasional Variabel}

Tabel 2

Definisi Operasional Variabel 


\begin{tabular}{|c|c|c|c|c|}
\hline No & Defenisi Variabel & $\begin{array}{c}\text { Jenis } \\
\text { Variabel }\end{array}$ & Indikator & $\begin{array}{c}\text { Skala } \\
\text { Pengukuran }\end{array}$ \\
\hline 2. & $\begin{array}{l}\text { karakteristik seorang pegawai dapat } \\
\text { dilihat dari umur, jenis kelamin, } \\
\text { status perkawinan, jumlah } \\
\text { tanggungan, masa kerja Handoko } \\
(2000: 111)\end{array}$ & bebas & $\begin{array}{l}\text { 2). Prosesudur } \\
\text { 3). Kepentingan } \\
\text { 4). Kewenangan } \\
\text { 5). Umpan balik } \\
\text { Handoko (2000:102) }\end{array}$ & $\begin{array}{l}\text { Skala } \\
\text { Ordinal }\end{array}$ \\
\hline 3. & $\begin{array}{l}\text { Motivasi adalah kesediaan untuk } \\
\text { mengeluarkan tingkat upaya yang } \\
\text { tinggi untuk tujuan organisasi yang } \\
\text { dikondisikan oleh kemampuan } \\
\text { upaya itu dalam memenuhi } \\
\text { beberapa kebutuhan individual } \\
\text { Hasibuan (2003:95) }\end{array}$ & $\begin{array}{l}\text { Variabel } \\
\text { bebas }\end{array}$ & $\begin{array}{l}\text { 1) Perhatian atasan } \\
\text { 2) Pengawasan } \\
\text { 3) Sanksi/hukuman } \\
\text { 4) Penghargaan } \\
\text { Hasibuan (2003:105) }\end{array}$ & $\begin{array}{l}\text { Skala } \\
\text { Ordinal }\end{array}$ \\
\hline 5. & $\begin{array}{l}\text { Kinerja pegawai merupakan hasil } \\
\text { yang dicapai oleh pegawai dalam } \\
\text { melaksanakan tugas-tugas yang } \\
\text { dibebankan kepadanya yang } \\
\text { didasarkan atas kecakapan, } \\
\text { kemudian pengalaman dan } \\
\text { keunggulan serta penggunaan } \\
\text { waktu. } \\
\text { Hasibuan (2008:86). }\end{array}$ & $\begin{array}{l}\text { Variabel } \\
\text { terikat }\end{array}$ & $\begin{array}{l}\text { 1) Kuantitas } \\
\text { 2) Kualitas } \\
\text { 3) Out put } \\
\text { 4) Waktu } \\
\text { 5) Kerjasama } \\
\text { Hasibuan (2008:95) }\end{array}$ & $\begin{array}{l}\text { Skala } \\
\text { Ordinal }\end{array}$ \\
\hline
\end{tabular}

\subsection{Teknik Analisis Data}

Uji validitas digunakan untuk mengukur sah atau valid tidaknya suatu kuesioner. Suatu kuesioner dikatakan valid jika pertanyaan pada kuesioner mampu untuk mengungkapkan sesuatu yang akan diukur oleh kuesioner tersebut. Metode yang digunakan untuk menguji validitas adalah melakukan korelasi antar skor butir pertanyaan dengan total skor konstruk atau variabel. Uji signifikansi dilakukan dengan membandingkan $\mathrm{r}$ hitung dengan $r$ table maka indikator dinyatakan valid dan sebaliknya jika $r$ tabel lebih kecil daripada $r$ hitung maka indikator dinyatakan tidak valid. Pengujian validitas ini dibantu dengan program SPSS vs. 20.00.

Uji reliabilitas sebenarnya adalah alat untuk mengukur suatu kuesioner yang merupakan indikator dari variabel atau konstruk. Suatu kuesioner dikatakan reliable atau handal jika jawaban seseorang terhadap pernyataan adalah konsisten atau stabil dari waktu ke waktu (Triton 2006:56). Menurut Triton (2006:57) pengukuran reliabilitas dapat dilakukan dengan dua cara yaitu :

a. Repeated Measure arau pengukuran ulang

Disini seseorang akan disodori pertanyaan yang sama pada waktu yang berbeda, dan kemudian dilihat apakah ia tetap konsisten dengan jawabannya. b. One Shot atau pengukuran sekali saja

Disini pengukurannya hanya sekali saja dan kemudian hasilnya dibandingkan dengan pertanyaan lain atau mengukur korelasi antar jawaban pertanyaan. SPSS yang memberikan fasilitas untuk mengukur reliabilitas dengan uji statistik Cronbach Alpha. Suatu konstruk atau variabel dikatakan reliable jika memberikan nilai Cronbach Alpha > 0,60. Dalam penelitian ini menggunakan one shot supaya lebih efisien dalam waktu penyelesaian penelitian.

\subsection{Uji Asumsi Klasik \\ 2.6.1 Uji Normalitas}

Uji normalitas bertujuan untuk menguji apakah dalam model regresi datanya terdistribusi normal atau tidak, model regresi yang baik jika distribusi datanya mengikuti distribusi normal atau mendekati normal, caranya adalah dengan melihat normal probability plot yang membandingkan distribusi kumulatif dari data sesungguhnya dengan distribusi kumulatif dari distribusi normal. Distribusi normal akan membentuk satu garis lurus diagonal, dan ploting data akan dibandingkan dengan garis diagonal. Jika distribusi data adalah normal, maka garis yang menggambarkan data sesungguhnya akan mengikuti garis diagonalnya atau dengan 
melihat kemencengan (skewness) dari grafik histogram. Model regresi dikatakan mengikuti distribusi normal apabila grafik histogram tidak menceng ke kiri dan ke kanan. Selain dengan normal probability plot, normalitas suatu data dapat juga diuji dengan uji KolmogorovSmirnov. Dari tabel One-Sample KolmogorovSmirnov Test diperoleh angka probabilitas atau Asym. Sig. (2-tailed). Nilai ini dibandingkan dengan 0,05 untuk pengambilan keputusan dengan pedoman

a. Nilai Sig. atau signifikansi atau nilai probabilitas < 0,05, maka dapat ditarik kesimpulan bahwa data tidak terdistribusi secara normal.

b. Nilai Sig. atau signifikansi atau nilai probabilitas >0,05, maka dapat ditarik kesimpulan bahwa data terdistribusi secara normal

\subsubsection{Uji Multikolinearitas}

Uji multikolinearitas bertujuan untuk mengetahui ada tidaknya variabel independen yang memiliki kemiripan dengan variabel independen lainnya dalam suatu model regresi, atau untuk mengetahui ada tidaknya korelasi diantara sesama variabel independen. Uji Multikolinearitas dilakukan dengan membandingkan nilai toleransi (tolerance value) dan nilai Variance Inflation Factor (VIF) dengan nilai yang disyaratkan. Nilai yang disyaratkan bagi nilai toleransi adalah lebih besar dari 0,01 , dan untuk nilai VIF kurang dari 10.

\subsubsection{Uji Heteroskedastisitas}

Uji heteroskedastisitas bertujuan menguji apakah dalam model regresi terjadi ketidaksamaan varian dari residual satu pengamatan ke pengamatan yang lain. Jika varian dari residual satu pengamatan ke pengamatan yang lain tetap, maka disebut Homoskedastisitas dan jika berbeda disebut heteroskedastisitas. Selain diukur dengan grafik Scaterplot, heteroskedastisitas dapat diukur secara sistematis dengan uji Glejser. Jika variabel bebas signifikan secara statistik mempengaruhi variabel terikat, maka ada indikasi terjadi heteroskedastisitas. Jika probabilitas signifikansinya di atas 0,05 , maka dapat disimpulkan tidak terjadi heteroskedastisitas.

\subsection{Pengujian Hipotesis}

Dalam penelitian ini untuk menguji hipotesis penelitian menggunakan analisis regresi linier berganda yaitu melihat pengaruh variabel independent (variabel bebas) terhadap variabel dependent (variabel terikat), dengan menggunakan persamaan matematis yaitu analisis regresi linier berganda dengan rumus :

$$
\mathrm{Y}=\mathrm{a}+\mathrm{b} 1 \mathrm{X} 1+\mathrm{b} 2 \mathrm{X} 2+\mathrm{b} 3 \mathrm{X} 3+\mathrm{e}
$$

Dimana :

Y1 = Kinerja pegawai

a $\quad=$ Konstanta

$\mathrm{X} 1=$ Kecerdasan emosional

$\mathrm{X} 2=$ Karakteristik pegawai

$\mathrm{X} 3=$ Motivasi kerja

b1,b2,b3 = Koefisien regresi

e $\quad=$ Standard error

\subsection{Uji F (Pengujian Simultan)}

Pengujian ini dilakukan untuk mengetahui apakah semua variabel independen secara bersama-sama (simultan) dapat berpengaruh terhadap variabel dependent. Cara yang digunakan adalah dengan membandingkan nilai $\mathrm{F}$ hitung dengan $\mathrm{F}$ tabel dengan ketentuan sebagai berikut :

H0 : $\beta=0$, berarti tidak ada pengaruh signifikan dari variabel independen terhadap variabel dependen secara simultan.

Ha : $\beta>0$, berarti ada pengaruh yang signifikan dari variabel independen terhadap variabel dependen secara simultan.

Tingkat kepercayaan yang digunakan adalah $95 \%$ atau taraf signifikan $5 \%(\alpha=0,05)$ dengan kriteria sebagai berikut :

a. Jika $\mathrm{F}$ hitung $>\mathrm{F}$ tabel dan probabilitas (nilai signifikan) < tingkat signifikansi 5\% $(\alpha=0,05)$ maka Ha diterima dan H0 ditolak berarti ada variabel independent secara bersama-sama mempunyai pengaruh yang signifikan terhadap variabel dependent.

b. Jika $\mathrm{F}$ hitung < $\mathrm{F}$ tabel dan probabilitas (nilai signifikansi) > tingkat signifikansi 5\% $(\alpha=0,05)$ maka H0 diterima dan Ha ditolak berarti ada variabel independent secara bersama-sama tidak ada pengaruh yang signifikan terhadap variabel dependent. Dimana $\mathrm{F}$ tabel ditentukan dengan mencari derajat bebasnya yaitu $\mathrm{df} 1=\mathrm{k}-1$ dan $\mathrm{df} 2=\mathrm{N}$ $\mathrm{k}$, dimana $\mathrm{N}=$ jumlah sampel dan $\mathrm{k}=$ jumlah variabel. 


\subsection{Uji t (Pengujian Secara Parsial)}

Uji t dilakukan untuk mengetahui pengaruh masing-masing variabel independen secara parsial terhadap variabel dependen. Uji $t$ dilakukan dengan embandingkan $t$ hitung terhadap $\mathrm{t}$ tabel dengan ketentuan sebagai berikut :

$\mathrm{H} 0: \beta=0$, berarti tidak ada pengaruh signifikan dari masing-masing variabel independen terhadap variabel dependen.

Ha : $\beta>0$, berarti ada pengaruh yang signifikan dari masing-masing variabel independen terhadap variabel dependen secara partial.

Tingkat kepercayaan yang digunakan adalah $95 \%$ atau taraf signifikan $5 \%(\alpha=0,05)$ dengan kriteria sebagai berikut :

a. Jika $\mathrm{t}$ hitung $>\mathrm{t}$ tabel dan probabilitas (nilai signifikan $)<$ tingkat signifikansi 5\% $(\alpha=$ $0,05)$ maka Ha diterima dan H0 ditolak berarti ada pengaruh yang signifikan dari masing-masing variabel independen terhadap variabel dependen.

b. Jika t hitung $<\mathrm{t}$ tabel dan probabilitas (nilai signifikansi) $>$ tingkat signifikansi $5 \%(\alpha=$ 0,05) maka H0 diterima dan Ha ditolak berarti tidak ada pengaruh yang signifikan dari masing-masing variabel independen terhadap variabel dependen. Dimana t tabel ditentukan dengan mencari derajat bebasnya yaitu $\mathrm{df}=\mathrm{N}-\mathrm{k}$.

\subsection{Koefisien Determinasi $\left(\mathbf{R}^{2}\right)$}

Koefisien determinasi $\left(\mathrm{R}^{2}\right)$ pada intinya mengukur seberapa besar kemampuan variabel independent yaitu (X1), (X2) dan (X3) dalam menerangkan variasi variabel dependent $(\mathrm{Y})$.
Nilai koefisien determinasi adalah antara nol (0) sampai dengan satu (1). Nilai $\mathrm{R}^{2}$ yang kecil berarti kemampuan variabel-variabel independent dalam menjelaskan variasi variabel dependent amat terbatas. Nilai yang mendekati satu berarti variabel-variabel independent memberikan hampir semua informasi yang dibutuhkan untuk memprediksi variasi dependent. Secara umum koefisien determinasi untuk data silang (crosssection) relatif rendah karena adanya variasi yang besar antara masing-masing pengamatan, sedangkan untuk data runtun waktu (time series) biasanya mempunyai nilai koefisien determinasi yang tinggi. Kelemahan mendasar penggunaan koefisien determinasi adalah bias terhadap jumlah variabel independent yang dimasukkan kedalam model. Setiap tambahan satu variabel independent, maka $\mathrm{R}^{2}$ pasti meningkat tidak peduli apakah variabel tersebut berpengaruh secara signifikan terhadap variabel dependent. Oleh karena itu banyak peneliti menganjurkan untuk menggunakan nilai Adjusted $R^{2}$ (Adjusted $R$ Square) pada saat mengevaluasi dimana model regresi terbaik. Tidak seperti $\mathrm{R}^{2}$, nilai Adjusted $\mathrm{R}^{2}$ dapat naik atau turun apabila satu variabel independent ditambahkan ke dalam model. Untuk variabel independent lebih dari dua sebaiknya menggunakan nilai Adjusted $\mathrm{R}^{2}$.

\section{Hasil dan Pembahasan \\ 3.1. Uji Validitas}

Uji validitas adalah uji statistik yang digunakan untuk menentukan seberapa valid suatu item pernyataan dalam mengukur variabel yang diteliti. Berikut ini hasil uji validitas dari keempat variabel yang diteliti.

Tabel 3

Out put uji vaiditas

\begin{tabular}{|c|c|c|c|c|}
\hline Variabel & Angket & $\mathrm{r}>0.3$ & Sig $<0.05$ & Keterangan \\
\hline \multirow{3}{*}{$\begin{array}{c}\text { Kecerdasan } \\
\text { emosional } \\
\left(\mathrm{X}_{1}\right)\end{array}$} & $\mathrm{X}_{1.1}$ & 0.745 & 0.000 & Valid \\
\cline { 2 - 5 } & $\mathrm{X}_{1.2}$ & 0.822 & 0.000 & Valid \\
\cline { 2 - 5 } & $\mathrm{X}_{1.3}$ & 0.510 & 0.000 & Valid \\
\cline { 2 - 5 } & $\mathrm{X}_{1.4}$ & 0.487 & 0.000 & Valid \\
\cline { 2 - 5 } & $\mathrm{X}_{1.5}$ & 0.717 & 0.000 & Valid \\
\cline { 2 - 5 } & $\mathrm{X}_{1.6}$ & 0.343 & 0.001 & Valid \\
\cline { 2 - 5 } & $\mathrm{X}_{1.7}$ & 0.737 & 0.000 & Valid \\
\cline { 2 - 5 } & $\mathrm{X}_{1.8}$ & 0.653 & 0.000 & Valid \\
\cline { 2 - 5 } & $\mathrm{X}_{1.9}$ & 0.664 & 0.000 & Valid \\
\cline { 2 - 5 } & $\mathrm{X}_{1.10}$ & 0.717 & 0.000 & Valid \\
\hline
\end{tabular}

Sumber : Hasil Pengolahan Data, 2019

Dari Tabel 3, di atas dapat dijelaskan bahwa nilai signifikansi butir-butir pernyataan untuk variabel kecerdasan emosional keseluruhannya dinyatakan valid, karena nilai korelasinya lebih besar dari 0.3 dan nilai signifikansinya di bawah 0.05 . 
Tabel 4

Out put uji vaiditas

\begin{tabular}{|c|c|c|c|c|}
\hline Variabel & Angket & $\mathrm{r}>0.3$ & Sig $<0.05$ & Keterangan \\
\hline $\begin{array}{c}\text { Karakteristik } \\
\text { pegawai }\end{array}$ & $\mathrm{X}_{2.1}$ & 0.708 & 0.000 & Valid \\
\cline { 2 - 5 }$\left(\mathrm{X}_{2}\right)$ & $\mathrm{X}_{2.2}$ & 0.856 & 0.000 & Valid \\
\cline { 2 - 5 } & $\mathrm{X}_{2.3}$ & 0.543 & 0.000 & Valid \\
\cline { 2 - 5 } & $\mathrm{X}_{2.4}$ & 0.569 & 0.000 & Valid \\
\hline Variabel & Angket & $\mathrm{r}>0.3$ & Sig $<0.05$ & Keterangan \\
\hline \multirow{5}{*}{} & $\mathrm{X}_{2.5}$ & 0.794 & 0.000 & Valid \\
\cline { 2 - 5 } & $\mathrm{X}_{2.6}$ & 0.321 & 0.000 & Valid \\
\cline { 2 - 5 } & $\mathrm{X}_{2.7}$ & 0.761 & 0.000 & Valid \\
\cline { 2 - 5 } & $\mathrm{X}_{2.8}$ & 0.700 & 0.000 & Valid \\
\cline { 2 - 5 } & $\mathrm{X}_{2.9}$ & 0.664 & 0.000 & Valid \\
\cline { 2 - 5 } & $\mathrm{X}_{2.10}$ & 0.786 & 0.000 & Valid \\
\hline
\end{tabular}

Sumber : Hasil Pengolahan Data, 2019

Dari Tabel 4, di atas dapat dijelaskan bahwa keseluruhannya dinyatakan valid, karena nilai signifikansi butir-butir pernyataan nilai korelasinya lebih besar dari 0.3 dan untuk variabel karakteristik pegawai nilai signifikansinya di bawah 0.05 .

\section{Tabel 5}

Out put uji vaiditas

\begin{tabular}{|c|c|c|c|c|}
\hline Variabel & Angket & $\mathrm{r}>0.3$ & Sig $<0.05$ & Keterangan \\
\hline \multirow{4}{*}{$\begin{array}{c}\text { Motivasi } \\
\left(\mathrm{X}_{3}\right)\end{array}$} & $\mathrm{X}_{3.1}$ & 0.456 & 0.000 & Valid \\
\cline { 2 - 5 } & $\mathrm{X}_{3.2}$ & 0.490 & 0.000 & Valid \\
\cline { 2 - 5 } & $\mathrm{X}_{3.3}$ & 0.560 & 0.000 & Valid \\
\cline { 2 - 5 } & $\mathrm{X}_{3.4}$ & 0.610 & 0.000 & Valid \\
\cline { 2 - 5 } & $\mathrm{X}_{3.5}$ & 0.596 & 0.000 & Valid \\
\cline { 2 - 5 } & $\mathrm{X}_{3.6}$ & 0.620 & 0.000 & Valid \\
\cline { 2 - 5 } & $\mathrm{X}_{3.7}$ & 0.619 & 0.000 & Valid \\
\cline { 2 - 5 } & $\mathrm{X}_{3.8}$ & 0.760 & 0.000 & Valid \\
\cline { 2 - 5 } & $\mathrm{X}_{3.9}$ & 0.614 & 0.000 & Valid \\
\cline { 2 - 5 } & $\mathrm{X}_{3.10}$ & 0.643 & 0.000 & Valid \\
\hline
\end{tabular}

Sumber : Hasil Pengolahan Data, 2019

Dari Tabel 5. di atas dapat dijelaskan keseluruhannya dinyatakan valid, karena bahwa nilai signifikansi butir-butir nilai korelasinya lebih besar dari 0.3 dan pernyataan untuk variabel motivasi nilai signifikansinya di bawah 0.05 .

\section{Tabel 6}

Out put uji vaiditas

\begin{tabular}{|c|c|c|c|c|}
\hline Variabel & Angket & $r>0.3$ & Sig $<0.05$ & Keterangan \\
\hline \multirow{10}{*}{$\begin{array}{l}\text { Kinerja } \\
(\mathrm{Y})\end{array}$} & $\mathrm{Y}_{1}$ & 0.780 & 0.000 & Valid \\
\hline & $\mathrm{Y}_{2}$ & 0.668 & 0.000 & Valid \\
\hline & $\mathrm{Y}_{3}$ & 0.636 & 0.000 & Valid \\
\hline & $\mathrm{Y}_{4}$ & 0.477 & 0.000 & Valid \\
\hline & $\mathrm{Y}_{5}$ & 0.422 & 0.000 & Valid \\
\hline & $\mathrm{Y}_{6}$ & 0.651 & 0.000 & Valid \\
\hline & $\mathrm{Y}_{7}$ & 0.502 & 0.000 & Valid \\
\hline & $Y_{8}$ & 0.762 & 0.000 & Valid \\
\hline & $Y_{9}$ & 0.871 & 0.000 & Valid \\
\hline & $Y_{10}$ & 0.342 & 0.025 & Valid \\
\hline
\end{tabular}

Sumber : Hasil Pengolahan Data, 2019 
Dari Tabel 6, di atas dapat dijelaskan bahwa nilai signifikansi butir-butir pernyataan untuk variabel kinerja keseluruhannya dinyatakan valid, karena nilai korelasinya lebih besar dari 0.3 dan nilai signifikansinya di bawah 0.05 .

\subsection{Uji Reliabilitas}

Uji reliabilitas adalah uji statistik yang digunakan untuk menentukan reliabilitas serangkaian item pernyataan dalam kehandalannya mengukur suatu variabel. Berikut ini hasil uji reliabilitas dari keempat variabel yang diteliti.

Tabel 7

Uji Reliabilitas

\begin{tabular}{|l|c|c|c|}
\hline \multicolumn{1}{|c|}{ Variabel } & $\begin{array}{c}\text { Nilai Alpha } \\
\text { Cronbach's }\end{array}$ & Reliabel/Tidak Reliabel & Keterangan \\
\hline Kecerdasan Emosional $\left(\mathrm{X}_{1}\right)$ & 0.842 & Reliabel (Tinggi) & Dipakai \\
\hline Karakteristik Pegawai $\left(\mathrm{X}_{2}\right)$ & 0.867 & Reliabel (Cukup) & Dipakai \\
\hline Motivasi Kerja $\left(\mathrm{X}_{3}\right)$ & 0.788 & Reliabel (Tinggi) & Dipakai \\
\hline Kinerja $(\mathrm{Y})$ & 0.792 & Reliabel (Cukup) & Dipakai \\
\hline
\end{tabular}

Sumber : Hasil Pengolahan Data, 2019

Dari Tabel 7, diatas, diketahui nilai $r_{\text {tabel }}$ untuk uji dua sisi pada tingkat signifikan 5\% $(\alpha=$ $0,05)$, dengan jumlah sample $\mathrm{N}=86$., maka derajat bebasnya adalah $\mathrm{N}-2=86-2=84$, dan diketahui nilai $r_{\text {tabel }}=0.211$. Dari hasil pengolahan data penelitian diperoleh nilai $\mathrm{r}_{\text {hitung }}$ pada kolom cronbach's alpha if item deleted semua lebih besar dari nilai $r_{\text {tabel}}$, maka seluruh butir pernyataan untuk variabel kecerdasan emosional dinyatakan reliabel.

\subsection{Uji Asumsi Klasik}

\subsubsection{Uji Normalitas}

Uji normalitas adalah untuk melihat apakah nilai residual terdistribusi normal atau tidak. Model regresi yang baik adalah memiliki nilai residual yang terdistribusi normal. Jadi uji normalitas bukan dilakukan pada masing-masing variabel tetapi pada nilai residualnya. Sering terjadi kesalahan yang jamak yaitu bahwa uji normalitas dilakukan pada masing-masing variabel. Hal ini tidak dilarang tetapi model regresi memerlukan normalitas pada nilai residualnya bukan pada masing-masing variabel penelitian.

Pengujian normalitas data penelitian adalah untuk menguji apakah dalam model statistik variabel-variabel penelitian berdistribusi normal atau tidak normal. Model regresi yang tinggi adalah memiliki distribusi normal atau mendekati normal. Untuk menguji apakah distribusi data normal atau tidak, salah satunya dengan menggunakan metode gambar normal Probabilitas Plots digunakan untuk menyimpulkan apakah model analisis memenuhi asumsi normal, dengan penyebaran data di sekitar garis diagonal dan mengikuti arah garis diagonal maka data tersebut mememenuhi asumsi normal dalam model analisis, yang dapat dilihat pada gambar dibawah ini :

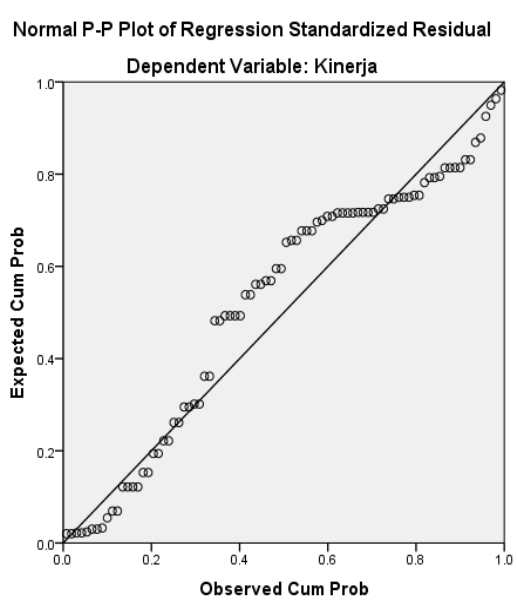

Gambar 1 Uji asumsi normalitas

Dari Gambar 1, diatas dapat dijelaskan bahwa penyebaran data berada di sekitar garis diagonal dan mengikuti arah garis diagonal, maka dapat ditarik kesimpulan data tersebut mememenuhi asumsi normal atau berdistribusi normal. Selanjutnya uji normalitas data juga dapat menggunakan uji Kolmogorov-Smirnov Test, dengan hasil sebagai berikut. 
Tabel 8

One-Sample Kolmogorov-Smirnov Test

\begin{tabular}{|l|l|r|}
\hline \multicolumn{2}{|l|}{} & Unstandardized Residual \\
\hline $\mathrm{N}$ & Mean & 86 \\
\cline { 2 - 3 } Normal Parameters & Std. Deviation & $0 \mathrm{E}-7$ \\
\hline \multirow{3}{*}{ Most Extreme Differences } & Absolute & 1.89106266 \\
\cline { 2 - 3 } & Positive & .155 \\
\cline { 2 - 3 } & Negative & .094 \\
\hline Kolmogorov-Smirnov Z & .155 \\
\hline Asymp. Sig. (2-tailed) & 1.436 \\
\hline \multicolumn{2}{|l|}{ Sumber : Hasil pengolahan data, 2019} & .062 \\
\hline
\end{tabular}

Berdasarkan Tabel 5.16, diatas diketahui signifikansi sebesar 0.062. Nilai signifikansi ini lebih besar dari 0.05, sehingga dapat disimpulkan bahwa data yang diuji berdistribusi normal.

\subsubsection{Uji Multikolinieritas}

Multikolinieritas berarti adanya hubungan yang kuat diantara beberapa atau semua variabel bebas pada model regresi. Jika terdapat multikolinieritas maka koefisien regresi menjadi tidak tentu, tingkat kesalahannya menjadi sangat besar dan biasanya ditandai dengan koefisien determinasi yang sangat besar tetapi pada pengujian parsial koefisien regresi, tidak ada atau pun kalau ada sangat sedikit sekali koefisien regresi yang signifikan. Pada penelitian ini digunakan nilai Variance Inflantion Factorrs (VIF) sebagai indikator ada tidaknya multikolinearitas di antara variabel bebas.

Tabel 9

Uji asumsi multikolinieritas

\begin{tabular}{|l|c|c|}
\hline \multirow{2}{*}{ Variabel } & \multicolumn{2}{|c|}{ Collinearity Statistics } \\
\cline { 2 - 3 } & Tolerance & VIF \\
\hline $\begin{array}{l}\text { Kecerdasan } \\
\text { emosional }\end{array}$ & 0.970 & 1.030 \\
\hline $\begin{array}{l}\text { Karakteristik } \\
\text { pegawai }\end{array}$ & 0.882 & 1.134 \\
\hline
\end{tabular}

\begin{tabular}{|c|c|c|}
\hline \multirow{2}{*}{ Variabel } & \multicolumn{2}{|c|}{ Collinearity Statistics } \\
\cline { 2 - 3 } & Tolerance & VIF \\
\hline Motivasi kerja & 0.858 & 1.165 \\
\hline
\end{tabular}

a Dependent Variable : Kinerja

Dari Tabel 9, dapat dijelaskan bahwa nilai Collinearity Statistics untuk nilai Variance Inflantion Factorrs (VIF) yang diperoleh dalam penelitian ini sebesar $1.030 ; 1.134$; 1.165, dan nilai tolerance sebesar $0.970 ; 0.882$; 0.858 ; dimana nilai Variance Inflantion Factorrs (VIF) dari ketiga varibel bebas dalam penelitian ini lebih kecil dari 10 dan dapat disimpulkan tidak terjadi multikolinieritas diantara ketiga variabel bebas dalam penelitian ini.

\subsubsection{Uji Autokorelasi}

Autokorelasi sebagai suatu korelasi antara nilai variabel dengan nilai variabel yang sama satu atau lebih. Menurut Cornelius (2005:212), kisaran nilai uji autokorelasi yang dilakukan dalam pengujian Durbin Watson (DW) sebagai berikut :

$1.65<\mathrm{DW}<2.35$ tidak terjadi autokorelasi 1.21. $<$ DW $<1.65$ atau $2.35<\mathrm{DW}<2.79$ tidak dapat disimpulkan.

$\mathrm{DW}<1.21$ atau DW $>2.79$ terjadi autokorelasi.

Tabel 10

Model summary

\begin{tabular}{|l|r|r|r|r|r|r|}
\hline \multirow{3}{*}{ Model } & \multicolumn{5}{|c|}{ Change Statistics } & \multirow{2}{*}{$\begin{array}{c}\text { Durbin- } \\
\text { Watson }\end{array}$} \\
\cline { 2 - 6 } & $\begin{array}{c}\text { R Square } \\
\text { Change }\end{array}$ & F Change & df1 & df2 & $\begin{array}{c}\text { Sig. F } \\
\text { Change }\end{array}$ & \\
\hline 1 & .646 & 49.962 & 3 & 82 & .000 & 1.901 \\
\hline
\end{tabular}

a Predictors: (Constant), Kecerdasan, Karakteristik, Motivasi

Dependent Variable: Kinerja

Hasil pengolahan data, 2019 
Berdasarkan Tabel 10, di atas diperoleh nilai statistik Durbin-Watson (DW) sebesar 1.901, nilai tersebut berada pada kisaran $1.65<\mathrm{DW}<$ 2.35 maka dapat disimpulkan tidak terdapat autokorelasi pada model regresi dalam penelitian ini.

\subsection{Analisis Regresi Linier Berganda}

Tabel 11

Coefficients

\begin{tabular}{|c|c|c|c|c|c|c|}
\hline \multirow{2}{*}{\multicolumn{2}{|c|}{ Model }} & \multicolumn{2}{|c|}{$\begin{array}{c}\text { Unstandardized } \\
\text { Coefficients }\end{array}$} & \multirow{3}{*}{$\begin{array}{c}\text { Standardized } \\
\text { Coefficients } \\
\text { Beta } \\
\end{array}$} & \multirow{2}{*}{$\mathrm{t}$} & \multirow{2}{*}{ Sig. } \\
\hline & & B & Std. Error & & & \\
\hline \multirow[t]{4}{*}{1} & (Constant) & 3.883 & 3.869 & & 1.004 & .319 \\
\hline & $\begin{array}{l}\text { Kecerdasan } \\
\text { emosional }\end{array}$ & .110 & .060 & .222 & 2.829 & .021 \\
\hline & $\begin{array}{l}\text { Karakteristik } \\
\text { pegawai }\end{array}$ & .593 & .063 & .655 & 9.371 & .000 \\
\hline & Motivasi kerja & .200 & .053 & .267 & 3.771 & .000 \\
\hline
\end{tabular}

Berdasarkan Tabel 11, out put SPSS "Coefficients" diatas, persamaan regresi linier berganda adalah sebagai berikut:

$\mathrm{Y}=3.883+0.110 \mathrm{X} 1+0.593 \mathrm{X} 2+0.200 \mathrm{X} 3$

Berdasarkan persamaan regresi linier berganda ini, maka dapat dijelaskan maksud dari persamaan di atas :

1. Nilai konstanta dari persamaan regresi dari penelitian ini sebesar 3.870, hal ini menyatakan bahwa nilai variabel kinerja pegawai di Kantor Pelayanan Pajak Pratama Medan Timur sebesar 3.883.

2. Koefisien regresi untuk variabel kecerdasan organiasi sebesar 0.110 , hal ini menjelaskan bahwa variabel kecerdasan emosional berpengaruh positif terhadap kinerja pegawai Kantor Pelayanan Pajak Pratama Medan Timur.

3. Koefisien regresi untuk variabel karakteristik pegawai sebesar 0.593 , hal ini menjelaskan bahwa variabel karakteristik pegawai berpengaruh positif terhadap kinerja pegawai Kantor Pelayanan Pajak Pratama Medan Timur.

4. Koefisien regresi untuk variabel motivasi kerja sebesar 0.200, hal ini menjelaskan bahwa variabel motivasi berpengaruh positif terhadap kinerja pegawai Kantor Pelayanan Pajak Pratama Medan Timur.

Dari persamaan di atas dapat ditarik kesimpulan bahwa model regresi ini sudah layak dan benar, dan dapat dijelaskan bahwa
Analisis regresi linier berganda ini digunakan untuk mengestimasi pengaruh kecerdasan emosional, karakteristik pegawai dan motivasi kerja terhadap kinerja pegawai di Kantor Pelayanan Pajak Pratama Medan Timur. Berdasarkan hasil pengolahan data diperoleh hasil sebagai berikut : variabel kecerdasan emosional, karakteristik pegawai dan motivasi kerja berpengaruh positif terhadap kinerja pegawai di Kantor Pelayanan Pajak Pratama Medan Timur.

\subsection{Uji Hipotesis}

3.5.1. Pengaruh Kecerdasan Emosional Terhadap Kinerja Pegawai di Kantor Pelayanan Pajak Pratama Medan Timur.

Untuk mengetahui pengaruh kecerdasan emosional terhadap kinerja pegawai di Kantor Pelayanan Pajak Pratama Medan Timur digunakan uji-t, dengan ketentuan sebagai berkut :

1. Jika nilai $t_{\text {hitung }}>t_{\text {tabel }}$ dan nilai probabilitas (p) $<$ tingkat signifikansi $5 \%(\alpha=0,05)$ maka hipotesis penelitian $\left(\mathrm{H}_{1}\right)$ diterima dan $\mathrm{H}_{0}$ ditolak, berarti ada pengaruh signifikan antara kecerdasan emosional terhadap kinerja.

2. Jika nilai $\mathrm{t}_{\text {hitung }}<\mathrm{t}_{\text {tabel }}$ dan nilai probabilitas (p) > tingkat signifikansi 5\% $(\alpha=0,05)$ maka hipotesis penelitian $\left(\mathrm{H}_{1}\right)$ ditolak dan $\mathrm{H}_{0}$ diterima, berarti tidak ada pengaruh signifikan antara kecerdasan emosional terhadap kinerja .

Penelitian ini menggunakan taraf signifikansi $(\alpha \quad 0,05)$ dan Derajat Kebebasan (DK) dengan ketentuan DK $=\mathrm{n}-2$, atau $86-2$ $=84$. Dengan ketentuan tersebut, diperoleh nilai $\mathrm{t}_{\text {tabel }}$ sebesar 1.988 . 
Tabel. 12

Coeficients $^{\mathrm{a}}$

\begin{tabular}{|c|c|c|c|c|c|c|}
\hline \multirow{2}{*}{\multicolumn{2}{|c|}{ Model }} & \multicolumn{2}{|c|}{$\begin{array}{c}\text { Unstandardized } \\
\text { Coefficients }\end{array}$} & \multirow{2}{*}{$\begin{array}{c}\text { Standardized } \\
\text { Coefficients } \\
\text { Beta } \\
\end{array}$} & \multirow{2}{*}{$\mathrm{t}$} & \multirow{2}{*}{ Sig. } \\
\hline & & $\mathrm{B}$ & Std. Error & & & \\
\hline 1 & (Constant) & 3.883 & 3.869 & & 1.004 & .319 \\
\hline & $\begin{array}{l}\text { Kecerdasan } \\
\text { emosional }\end{array}$ & 囵. & .060 & .222 & 2.829 & .021 \\
\hline
\end{tabular}

a Dependent Variable : Kinerja

Hasil pengolahan data, 2019

Berdasarkan Tabel 12, out put SPSS "Coeficients" diatas diketahui nilai $t_{\text {hitung }}$ variabel kecerdasan emosional sebesar 2.829. Karena nilai $t_{\text {hitung }}>t_{\text {tabel }}(2.829>1.988)$ dan nilai signifikasi $0.021<0.05$, sehingga $\mathrm{H}_{0}$ ditolak dan $\mathrm{H}_{1}$ diterima. Artinya hipotesis yang diajukan dalam penelitian ini diterima yaitu variabel kecerdasan emosional secara partial berpengaruh positif dan signifikan terhadap kinerja pegawai di Kantor Pelayanan Pajak Pratama Medan Timur. Hasil penelitian ini menjelaskan bahwa semakin baik kecerdasan emosional maka semakin tinggi kinerja pegawai di Kantor Pelayanan Pajak Pratama Medan Timur.

\subsubsection{Pengaruh Karakteristik Pegawai Terhadap Kinerja Pegawai di Kantor Pelayanan Pajak Pratama Medan Timur.}

Untuk mengetahui pengaruh karakteristik pegawai terhadap kinerja pegawai di Kantor Pelayanan Pajak Pratama Medan Timur digunakan uji-t, dengan ketentuan sebagai berkut :

1. Jika nilai $t_{\text {hitung }}>t_{\text {tabel }}$ dan nilai probabilitas (p) $<$ tingkat signifikansi 5\% $(\alpha=0,05)$ maka hipotesis penelitian $\left(\mathrm{H}_{1}\right)$ diterima dan $\mathrm{H}_{0}$ ditolak, berarti ada pengaruh signifikan antara karakteristik pegawai terhadap kinerja

2. Jika nilai $t_{\text {hitung }}<t_{\text {tabel }}$ dan nilai probabilitas (p) > tingkat signifikansi $5 \%(\alpha=0,05)$ maka hipotesis penelitian $\left(\mathrm{H}_{1}\right)$ ditolak dan $\mathrm{H}_{0}$ diterima, berarti tidak ada pengaruh signifikan antara karakteristik pegawai terhadap kinerja .

Penelitian ini menggunakan taraf signifikansi $(\alpha \quad 0,05)$ dan Derajat Kebebasan (DK) dengan ketentuan DK $=\mathrm{n}-2$, atau $86-2$ $=84$. Dengan ketentuan tersebut, diperoleh nilai $\mathrm{t}_{\text {tabel }}$ sebesar 1.988 .

Tabel. 13

Coeficients $^{\mathrm{a}}$

\begin{tabular}{|c|c|c|c|c|c|c|}
\hline \multirow{2}{*}{\multicolumn{2}{|c|}{ Model }} & \multicolumn{2}{|c|}{$\begin{array}{l}\text { Unstandardized } \\
\text { Coefficients }\end{array}$} & \multirow{3}{*}{$\begin{array}{c}\text { Standardized } \\
\text { Coefficients } \\
\text { Beta }\end{array}$} & \multirow{2}{*}{$\mathrm{t}$} & \multirow{2}{*}{ Sig. } \\
\hline & & B & Std. Error & & & \\
\hline 1 & (Constant) & 3.883 & 3.869 & & 1.004 & .319 \\
\hline & $\begin{array}{l}\text { Karakteristik } \\
\text { pegawai }\end{array}$ & .593 & .063 & .655 & 9.371 & .000 \\
\hline
\end{tabular}

a Dependent Variable : Kinerja

Hasil pengolahan data, 2019

Berdasarkan Tabel 13, out put SPSS "Coeficients" diatas diketahui nilai $\mathrm{t}_{\text {hitung }}$ variabel karakteristik pegawai sebesar 9.371. Karena nilai $\mathrm{t}_{\text {hitung }}>\mathrm{t}_{\text {tabel }}(9.371>1.988)$ dan nilai signifikasi $0.000<0.05$, sehingga $\mathrm{H}_{0}$ ditolak dan $\mathrm{H}_{1}$ diterima. Artinya hipotesis yang diajukan dalam penelitian ini diterima yaitu variabel karakteristik pegawai secara partial berpengaruh positif dan signifikan terhadap kinerja pegawai di Kantor
Pelayanan Pajak Pratama Medan Timur. Hasil penelitian ini menjelaskan bahwa semakin baik karakteristik pegawai maka semakin tinggi kinerja pegawai di Kantor Pelayanan Pajak Pratama Medan Timur.

\subsubsection{Pengaruh Motivasi Kerja Terhadap Kinerja Pegawai di}


Kantor Pelayanan Pajak Pratama Medan Timur.

Untuk mengetahui pengaruh motivasi kerja terhadap kinerja pegawai di Kantor Pelayanan Pajak Pratama Medan Timur digunakan uji-t, dengan ketentuan sebagai berkut :

1. Jika nilai $t_{\text {hitung }}>t_{\text {tabel }}$ dan nilai probabilitas (p) $<$ tingkat signifikansi 5\% $(\alpha=0,05)$ maka hipotesis penelitian $\left(\mathrm{H}_{1}\right)$ diterima dan $\mathrm{H}_{0}$ ditolak, berarti ada pengaruh signifikan antara motivasi kerja terhadap kinerja .

Tabel. 14

Coeficients ${ }^{\mathrm{a}}$ pengaruh motivasi kerja terhadap kinerja

\begin{tabular}{|c|c|c|c|c|c|c|}
\hline \multirow{2}{*}{\multicolumn{2}{|c|}{ Model }} & \multicolumn{2}{|c|}{$\begin{array}{c}\text { Unstandardized } \\
\text { Coefficients }\end{array}$} & \multirow{2}{*}{$\begin{array}{c}\text { Standardized } \\
\text { Coefficients } \\
\text { Beta }\end{array}$} & \multirow{2}{*}{$\mathrm{t}$} & \multirow{2}{*}{ Sig. } \\
\hline & & B & Std. Error & & & \\
\hline 1 & (Constant) & 3.883 & 3.869 & & 1.004 & .319 \\
\hline & Motivasi kerja & .200 & .053 & .267 & 3.771 & .000 \\
\hline
\end{tabular}

Hasil pengolahan data, 2019

Berdasarkan Tabel 14, out put SPSS "Coeficients" diatas diketahui nilai $\mathrm{t}_{\text {hitung }}$ variabel motivasi kerja sebesar 3.771. Karena nilai $\mathrm{t}_{\text {hitung }}>\mathrm{t}_{\text {tabel }}(3.771>1.988)$ dan nilai signifikasi $0.000<0.05$, sehingga $\mathrm{H}_{0}$ ditolak dan $\mathrm{H}_{1}$ diterima. Artinya hipotesis yang diajukan dalam penelitian ini diterima yaitu variabel motivasi kerja secara partial berpengaruh positif dan signifikan terhadap kinerja pegawai di Kantor Pelayanan Pajak Pratama Medan Timur. Hasil penelitian ini menjelaskan bahwa semakin baik motivasi kerja maka semakin tinggi kinerja pegawai di Kantor Pelayanan Pajak Pratama Medan Timur.

\subsubsection{Pengaruh Kecerdasan Emosional, Karakteristik Pegawai dan Motivasi Kerja Terhadap Kinerja Pegawai di Kantor Pelayanan Pajak Pratama Medan Timur.}

Untuk mengetahui pengaruh kecerdasan emosional, karakteristik pegawai dan motivasi kerja terhadap kinerja pegawai di
2. Jika nilai $t_{\text {hitung }}<t_{\text {tabel }}$ dan nilai probabilitas (p) > tingkat signifikansi 5\% $(\alpha=0,05)$ maka hipotesis penelitian $\left(\mathrm{H}_{1}\right)$ ditolak dan $\mathrm{H}_{0}$ diterima, berarti tidak ada pengaruh signifikan antara motivasi kerja terhadap kinerja .

Penelitian ini menggunakan taraf signifikansi $(\alpha \quad 0,05)$ dan Derajat Kebebasan (DK) dengan ketentuan DK $=\mathrm{n}-2$, atau $86-2$ $=84$. Dengan ketentuan tersebut, diperoleh nilai $\mathrm{t}_{\text {tabel }}$ sebesar 1.988 .
Kantor Pelayanan Pajak Pratama Medan Timur digunakan uji-F, dengan ketentuan sebagai berkut :

1. Jika nilai $F_{\text {hitung }}>F_{\text {tabel }}$ dan nilai probabilitas (p) $<$ tingkat signifikansi $5 \%(\alpha=0,05)$ maka hipotesis penelitian $\left(\mathrm{H}_{1}\right)$ diterima dan $\mathrm{H}_{0}$ ditolak, berarti ada pengaruh signifikan antara kecerdasan emosional, karakteristik pegawai dan motivasi kerja terhadap kinerja

2. Jika nilai $\mathrm{F}_{\text {hitung }}<\mathrm{F}_{\text {tabel }}$ dan nilai probabilitas (p) > tingkat signifikansi 5\% $(\alpha=0,05)$ maka hipotesis penelitian $\left(\mathrm{H}_{1}\right)$ ditolak dan $\mathrm{H}_{0}$ diterima, berarti tidak ada pengaruh signifikan antara kecerdasan emosional, karakteristik pegawai dan motivasi kerja terhadap kinerja .

Penelitian ini menggunakan taraf signifikansi $(\alpha \quad 0,05)$ dan Derajat Kebebasan (DK) dengan ketentuan numerator : jumlah variabel -1 atau $4-1=3$, dan jumlah sampel dikurang 4 atau $86-4=82$. Dengan ketentuan tersebut, diperoleh nilai $\mathrm{F}_{\text {tabel }}$ sebesar 2.49 .

Tabel 15

Anova $^{\mathrm{b}}$

\begin{tabular}{|l|l|r|r|r|r|c|}
\hline \multirow{2}{*}{ Model } & & $\begin{array}{c}\text { Sum of } \\
\text { Squares }\end{array}$ & \multicolumn{1}{c|}{ df } & $\begin{array}{c}\text { Mean } \\
\text { Square }\end{array}$ & \multicolumn{1}{c|}{ F } & Sig. \\
\hline \multirow{3}{*}{1} & Regression & 555.623 & 3 & 185.208 & 49.962 & $.000^{\mathrm{a}}$ \\
\cline { 2 - 7 } & Residual & 303.970 & 82 & 3.707 & & \\
\cline { 2 - 7 } & Total & 859.593 & 85 & & & \\
\hline
\end{tabular}

a Predictors: (Constant), Kecerdasan, Karakteristik, Motivasi

Dependent Variable : Kinerja 
Berdasarkan Tabel 15, out put SPSS "Anova" diatas diketahui nilai $\mathrm{F}_{\text {hitung }}>\mathrm{F}_{\text {tabel }}$ $(49.962>2.49)$ dan nilai signifikasi $0.000<$ 0.05 , sehingga $\mathrm{H}_{0}$ ditolak dan $\mathrm{H}_{1}$ diterima. Artinya variabel kecerdasan emosional, karakteristik pegawai dan motivasi kerja secara simultan atau bersama-sama berpengaruh positif dan signifikan terhadap kinerja pegawai di Kantor Pelayanan Pajak Pratama Medan Timur.

\subsection{Uji Determinan}

Uji determinan adalah untuk melihat seberapa besar pengaruh variabel kecerdasan emosional, karakteristik pegawai dan motivasi kerja terhadap kinerja pegawai di Kantor Pelayanan Pajak Pratama Medan Timur secara simultan, maka dapat dilihat dari hasil perhitungan dalam model summary, khususnya angka $R_{\text {Square }}$ dibawah ini :

Tabel 16

Model summary ${ }^{\mathrm{b}}$

\begin{tabular}{|l|c|r|r|r|}
\hline Model & $\mathrm{R}$ & $\mathrm{R}$ Square & $\begin{array}{c}\text { Adjusted R } \\
\text { Square }\end{array}$ & \multicolumn{1}{c|}{ Std. Error of the Estimate } \\
\hline 1 & $.804^{\mathrm{a}}$ & .646 & .633 & 1.92534 \\
\hline \multicolumn{2}{l|}{ a Predictors: (Constant), Kecerdasan, Karakteristik, Motivasi }
\end{tabular}

Dependent Variable: Kinerja

Berdasarkan Tabel 5.24, out put SPSS "Model summary" diatas, diperoleh nilai $\mathrm{R}_{\text {Square }}\left(\mathrm{r}^{2}\right)$ adalah 0.646. Nilai tersebut mempunyai maksud bahwa pengaruh variabel kecerdasan emosional, karakteristik pegawai dan motivasi kerja terhadap kinerja pegawai di Kantor Pelayanan Pajak Pratama Medan Timur sebesar $64.60 \%$, sedangkan sisanya sebesar $35.40 \%$ $(100 \%$ - 64.60\%) dipengaruhi oleh faktor-faktor lain yang tidak diteliti. Dengan kata lain variabilitas kinerja pegawai di Kantor Pelayanan Pajak Pratama Medan Timur dapat diterangkan oleh variabel kecerdasan emosional, karakteristik pegawai dan motivasi kerja sebesar $64.60 \%$, sedangkan sisanya sebesar $35.40 \%$ disebabkan oleh variabelvariabel lain yang tidak diteliti.

\section{Kesimpulan}

Berdasarkan analisis dan evaluasi data yang telah dijabarkan pada bab sebelumnya baik secara kualitatif maupun kuantitatif, maka dapat disusun kesimpulan dalam penelitian ini yaitu :

1. Variabel kecerdasan emosional berpengaruh positif dan signifikan terhadap kinerja pegawai pada Kantor Pelayanan Pajak Pratama Medan Timur. Hal ini berarti semakin baik kecerdasan emosional maka semakin tinggi kinerja pegawai.

2. Variabel karakteristik pegawai berpengaruh positif dan signifikan terhadap kinerja pegawai pada Kantor Pelayanan Pajak Pratama Medan Timur. Hal ini berarti semakin baik karakteristik pegawai maka semakin tinggi kinerja pegawai.

3. Variabel motivasi kerja berpengaruh positif dan signifikan terhadap kinerja pegawai pada Kantor Pelayanan Pajak Pratama Medan Timur. Hal ini berarti semakin baik motivasi kerja maka semakin tinggi kinerja pegawai.

4. Variabel kecerdasan emosional, karakteristik pegawai dan motivasi kerja berpengaruh positif dan signifikan terhadap kinerja pegawai pada Kantor Pelayanan Pajak Pratama Medan Timur. Hal ini berarti semakin baik kecerdasan emosional, karakteristik pegawai dan motivasi kerja maka semakin tinggi kinerja pegawai.

\section{DAFTAR PUSTAKA}

Babatunde, M.M., James, O.O., Ifeanyi, N.O., dan Olanrewaju, M.K. (2014). Work Motivation and Emotional Intelligence as Correlates of Secondary School Teachers" Productivity in South Western Nigeria. Multilingual Academic Journal of Education and Social Sciences, Vol. 2, No. 1

Dessler, Gary. (2007). Manajemen Sumber Daya Manusia (Jilid I). Jakarta : Indeks

Dubrin, Andrew J (2005). Leadership (Terjemahan), Edisi Kedua, Prenada Media, Jakarta.

Efendi, A., 2005. Revolusi Kecerdasan Abad 21. Kritik MI, EI,SQ, AQ \& successful intelligence atas IQ. Alfabeta, Jakarta

Goleman, D. 2008. Emotional Entellegent. PT. Gramedia Pustaka Utama, Jakarta

2005. Kecerdasan Emosional untuk Mencapai Puncak Prestasi. Cetakan Kelima. Gramedia Pustaka, Jakarta. Diterjemahkan oleh Alex Tri Kuntjahyo 
dari working With Emotional Intelligence, 1999

Handoko, T. Hani (2000), Manajemen, Edisi 2, BPFE, Yogyakarta

Istijanto (2008). Riset Sumber Daya Manusia, Cara Praktis Mendeteksi Dimensi-Dimensi Kerja Pegawai, Cetakan Ketiga, PT Gramedia, Jakarta

Hasibuan, Malayu, SP (2008), Manajemen Sumber Daya Manusia, PT. Bumi Akasara Jakarta.

Husnan, Keldjrachman Suad, (2004), Manajemen Personalia, Edisi ke Empat, BPFE Yogyakarta

Komaruddin (2007), Ensiklopedia Manajemen, Rineka Cipta, Jakarta

Mangkunegara, Anwar, Prabu. (2009). Evaluasi Kinerja SDM, Cetakan 4, Bandung : Refika Aditama

Manullang (2001), Manajemen Pengantar Ekonomi Perusahaan, Edisi Revisi, Cetakan Ke Enam Belas, BPFE, Yogyakarta

Martoyo, Susili (2004), Manajemen Sumber Daya Manusia, Edisi Ketiga, Cetakan Keempat, Ghalia Jakarta

Moekijat (2001), Latihan dan Pengembangan Sumber Daya Manusia, Cetakan ke Empat, Maju Mundur, Bandung

Nitisemito S Alex (2001), Manajemen Personalia, Cetakan Keempat, Ghalia, Jakarta.

Omollo, P.A., dan Oloko. (2015). Effect of motivation on employee performance of commercial banks in Kenya: A case study of Kenya Commercial Bank in Migori County. International Journal of Human Resource Studies Vol. 5, No. 2

Paisal dan Susi, A. (2010). Pengaruh Kecerdasan Emosional dan Kecerdasan Spritual terhadap Kinerja Pegawai pada LBPP-LIA Palembang. Jurnal Ilmiah Orasi Bisnis Edisi IV November

Rivai, Veithzal dan Sagala, Ella Jauvani. (2009). Manajemen Sumber Daya Manusia Untuk Perusahaan : Dari Teori ke Praktek. Jakarta : PT. Rajagrafindo Persada

Robbins, Stephen P (2008). Essentials of Organizational Behavior (Terjemahan), Edisi Kelima, Penerbit Erlangga, Jakarta

Saeed, S., dan Syah, F.M (2016). Impact of Performance Appraisal on Employee
Motivation in Islamic Banking. Arabian Journal of Business and Management Review (OMAN Chapter). Vol. 5, No.7; February 2016

Santoso Singgih (2004), Buku Latihan SPSS Statistik Parametrik, PT. Alex Media Komputindo Gramedia Jakarta.

Schroeder, Roger G (2004), Manajemen Operasi, Jilid I Erlangga Jakarta

Sedarmayanti (2007). Manajemen Sumber Daya Manusia, Reformasi Birokrasi dan Manajemen Pegawai Negeri Sipil, PT Refika Aditama Bandung

Siagian, SP (2003) Teori dan Praktek Pengambilan Keputusan, Cetakan II, CV. Haji Masagung, Jakarta

Schuler Randal S and Jackson Susan E, alih bahasa Prawira Hie (2007), Manajemen Sumber Daya Manusia, Penerbit Erlangga Jakarta

Shapiro, L.E., 2003. Mengajarkan emotional intelligence pada anak, PT Gramedia Pustaka Utama, Jakarta

Slamet (2011). Pengaruh Kompensasi Finansial, Gaya Kepemimpinan, dan Motivasi Kerja Terhadap Kinerja Pegawai pada Perusahaan Manufaktur di Jawa Timur. Jurnal Manajemen dan Kewirausaan, Vol 13, No 1.

Sontakke, J.P. (2016). Achievement Motivation and Emotional Intelligence: A Correlational Study. The International Journal of Indian Psychology Volume 3, Issue 2

Swastha DH, Basu dan Ibnu Sukotjo (2000), Pengantar Bisnis Modern, Edisi Revisi Liberty Yogyakarta

Svyantek, D.J., 2003. Emotional Entellegence and Organizational Behavior The International Journal of Organization Analysis 11(3): 167-169

Terry George \& Rue, Leslie W alih bahasa Sadeli (2008), Dasar-Dasar Manajemen, Cetakan Ketujuh Bumi Aksara Jakarta

Triton PB(2006), SPSS 12.00 Terapan Riset Statistik Parametrik, Andi Yogyakarta.

Wibowo (2014). Manajemen Kinerja, Edisi Kedua, PT RajaGrafindo Persada, Jakarta

Windy dan Gusnati (2012). Pengaruh Kompensasi, Motivasi dan Komitmen Organisasi terhadap Kinerja Pegawai bagian Akuntansi. The Indonesian Accounting Review, Volume 2, No. 2 